\title{
Entrepreneurial orientation and innovation intensity: A synthetic literature review
}

\author{
Nizar M. Benazzouz
}

\begin{tabular}{|c|c|}
\hline \multicolumn{2}{|r|}{ A B S T R ACT } \\
\hline \multicolumn{2}{|c|}{$\begin{array}{l}\text { Objective: This article reviews the empirical findings directly or indirectly linking Entrepre- } \\
\text { neurial Orientation to Innovation Intensity in the period 2008-2018. It also investigates the } \\
\text { fuzzy concept of Innovation Intensity and suggests some research avenues in the future. }\end{array}$} \\
\hline \multicolumn{2}{|c|}{$\begin{array}{l}\text { Research Design \& Methods: The research method is based on critical and synthetic } \\
\text { literature review. In a three-steps process, relevant papers were identified and clas- } \\
\text { sified. These samples were then analyzed and put into a perspective of the explaining } \\
\text { then linking the concepts of Entrepreneurial Orientation and Innovation Intensity. } \\
\text { Based on that, recommendations for future research are presented. }\end{array}$} \\
\hline \multicolumn{2}{|c|}{$\begin{array}{l}\text { Findings: Although many studies insinuate a positive relationship between Entrepre- } \\
\text { neurial Orientation and Innovation Intensity, there is no empirical research specifi- } \\
\text { cally targeting this link. The main reason seems to be a lack of clarity around the } \\
\text { concept of "Intensity" itself. }\end{array}$} \\
\hline \multicolumn{2}{|c|}{$\begin{array}{l}\text { Contribution \& Value Added: This study introduces a conceptualization of Innovation } \\
\text { Intensity based studying the extant literature. Furthermore, it is good starting point } \\
\text { for scholars interested in clarifying the concept of Innovation Intensity or/and deter- } \\
\text { mining the nature of relationship linking this latter and Entrepreneurial Orientation. }\end{array}$} \\
\hline Article type: & \\
\hline Keywords: & $n-$ \\
\hline & \\
\hline & \\
\hline
\end{tabular}

\section{Suggested citation:}

Benazzouz, N.M. (2019). Entrepreneurial orientation and Innovation Intensity: A synthetic literature review. International Entrepreneurship Review (previously published as International Entrepreneurship / Przedsiębiorczość Międzynarodowa), 5(2), 23-36. https://doi.org/10.15678/IER.2019.0502.02 


\section{INTRODUCTION}

Behaving with an entrepreneurial mindset and its benefits has gained vast grounds among researchers and business managers and has been pointed to as an important factor in determining the progress of companies and nations (Awang, Amran, Nor, Ibrahim, Razali, 2016). Namely, the relation between Entrepreneurial Orientation and firm performance has been of high interest, mostly in changing and competitive environments. In this regard, it may seem obvious that Entrepreneurial Orientation and Innovation Intensity (hereinafter labeled EO and II respectively) are highly correlated, mostly given the fact that innovativeness is a main component of EO construct. Yet, few empirical extant studies have tackled this issue.

The objective of this article is hence to discuss the concepts of EO and II by building upon previous empirical studies within the period 2008-2018 directly or indirectly linking them.

The methodology employed for this study is a synthetic and critical literature review of empirical studies around EO and innovation. The databases used for this purpose are (i) ScienceDirect and (ii) Scopus, as they contain the 'mainstream' of research papers in English.

This article contributes to the extant knowledge around innovation and entrepreneurship by displaying a positive correlation between many variants of both concepts in most sampled studies, while highlighting some noteworthy gaps.

At first, this study displays a summary of the literature review process. Afterward, a multi-dimensional construct of EO is introduced. A discussion of the concept of II comes next. The literature around the two main concepts of this study is hence discussed. A conclusion sums up the findings of the empirical literature review and suggests new research venues.

\section{MATERIAL AND METHODS}

This paper uses a critical and comparative analysis as a main research method. The selection of the pool of papers, which were used as a basis of our study, was run as a multi-step process. Firstly, a comprehensive screening of the terms "entrepreneurial orientation" AND "innovation intensity" was done in the databases of (i) ScienceDirect and (ii) Scopus. Few empirical articles were found at this initial stage, so we widened our research to "entrepreneurial orientation" AND "innovation" in keywords, entitled " $A$ "-list. 650 articles were found. Hence, in order to sort through the significant quantity of studies, a focus on the word "empirical" in Abstract, headline and keywords had to be made. The " $B$ "-list included 64 articles. Within this last sample, 39 articles were dropped because neither EO nor II (or variants) were considered their central variables. A " $C$ "-list hence included 25 articles among which 9 were selected as they highlighted a link between variants of EO and II. 6 additional papers which are not part of the " $C$ " - list seemed relevant to the study and thus were added as well (cf. Table 1). A summary of the results is presented at the end of this paper. 
Screening of list "A" for the term "entrepreneurial orientation" AND "innovation" in keywords

\begin{tabular}{|c|c|c|}
\hline "A"-list & Science Direct & Scopus \\
\hline \# papers & 90 & 560 \\
\hline
\end{tabular}

Screening of list "A" for the term "empirical" in abstract, headline and keywords

\begin{tabular}{|l|c|c|}
\hline "B"-list & Science Direct & Scopus \\
\hline \# papers & 26 & 38 \\
\hline
\end{tabular}

\begin{tabular}{|c|c|c|}
\hline "C"-list & Science Direct & Scopus \\
\hline \# papers relevant to the study & 11 & 14 \\
\hline $\begin{array}{l}\text { papers from list "C" kept for } \\
\text { this study (9) }\end{array}$ & \multicolumn{2}{|c|}{$\begin{array}{l}\text { Arzubiaga, Kotlar, Massis, Maseda, \& Iturralde (2018); } \\
\text { García, Llopis, Fernández, \& Alegre (2015); } \\
\text { Helm, Mauroner, \& Dowling (2010); } \\
\text { Jing, Edgar, Geare, \& O'Kane (2016); Jorge (2018); } \\
\text { Muslikh, Byarwati, \& Hidayati (2016); } \\
\text { Peng, Michael, \& Xiaofeng (2016); Renko, Carsrud, \& Brännback } \\
\text { (2009); Sheng, \& Chien (2016) }\end{array}$} \\
\hline
\end{tabular}

\begin{tabular}{|l|l|}
\hline $\begin{array}{l}\text { Additional papers comple- } \\
\text { menting “C"-list (6) }\end{array}$ & $\begin{array}{l}\text { Alegre, \& Chiva, (2013) ; Boso, Cadogan, \& Story (2012); } \\
\text { Liu, Ding, Guo, \& Luo (2014); } \\
\text { Perez-Luno, Wiklund, \& Valle Cabrera (2011); } \\
\text { Wu, Chang, \& Chen (2008); Yu, \& Si (2012) }\end{array}$ \\
\hline
\end{tabular}

Figure 1. The process applied for literature review Source: own elaboration.

\section{LITERATURE REVIEW}

\section{Entrepreneurial orientation}

Entrepreneurial orientation has been one of the most discussed and largely accepted constructs in the extant literature on entrepreneurship (Covin, Green \& Slevin, 2006; Wales, Gupta \& Mousa, 2013). Some scholars treat EO as a behavioral propensity and as 
an enabling framework that makes the firm entrepreneurial (Hosseini, 2012). In this regard, they tend to equate EO with intentions and attitudes rather than the core entrepreneurship itself although it is believed that both parts are quite complementary (Wach, 2015). Rauch, Wiklund, Lumpkin \& Frese (2009) linked EO with a higher strategic level by defining it as "the entrepreneurial strategy- making processes that key decision makers use to enact their firm's organizational purpose, sustain its vision and create competitive advantage(s)." Others followed suit and confirmed that EO incorporates firm-level processes, practices and decision-making styles where entrepreneurial behavioral patterns are recurring (Covin et al., 2006; Wach, 2015). Lumpkin and Dess (1996) emphasized the difference between EO and entrepreneurship by suggesting that the former "represents key entrepreneurial processes that answer the question of how new ventures are undertaken, whereas the term entrepreneurship refers to the content of entrepreneurial decisions by addressing what is undertaken."

5 dimensions conceptualize EO. Proactiveness, innovativeness and risk taking (Miller, 2011); the two complementary dimensions are autonomy and aggressiveness toward competitors (Lumpkin \& Dess, 1996). Risk taking refers to is the earliest and most frequently used characteristic of entrepreneurs. It seems obvious that the uncertainty and riskiness of self-employment is higher than normal employment. Risk, as the possibility of loss, may be viewed as an inherent characteristic of innovativeness, new business formation and aggressive or proactive actions of existing firms (Antoncic \& Hisrich, 2003). It is hence intertwined with the management will to take risk with regard to investment decisions and strategic actions in uncertain conditions (Covin \& Slevin, 1991). Innovativeness -which was considered the most important component of EO by some scholars (e.g. Eggers, Kraus, Hughes, Laraway, \& Snycerski, 2013), stands for the process related to changes in production functions whereby firms seek to acquire and build upon their distinctive technological competence (Therrien, Doloreux, \& Chamberlin, 2011). It can also be considered as the tendency of a firm to engage in and support new ideas, novelty, experimentation and creative processes that may result in new products and services (Dess \& Lumpkin, 1996). Proactiveness is an opportunity-seeking, forward looking perspective related to the introduction of new products and services ahead of the competition and acting in anticipation of future demand. Many scholars consider the anticipation and acting on future wants and needs in the marketplace that create a first mover advantage as a trait of proactiveness (Wiklund \& Shepherd, 2003). This dimension is hence critical for firms willing to capture high profits and establish brand recognition. The fourth dimension of EO is competitive aggressiveness. This latter refers to a firm's propensity to challenge its competitors to achieve entry or improve position, that is, to outperform industry rivals in the marketplace. The last dimension is autonomy. It is quite different from other EO dimensions. While all other EO dimensions are focused outward, autonomy is centered inward as a facilitator. It seems to be about independent spirit, which is a key to unlocking entrepreneurial potential. It also refers to the independent action of an individual or a team in bringing forward an idea or a vision and carrying it through to completion, without being held back by overly stringent organizational constraints (Burns, 2013). All EO dimensions are summarized in the table below. 
Table 1. A multi-construct of EO

\begin{tabular}{|c|c|l|}
\hline$\#$ & Construct Dimension & \multicolumn{1}{c|}{ Composite qualities } \\
\hline 1 & Proactiveness & $\begin{array}{l}\text { - predicting future market changes (Rauch et al., 2009) } \\
\text { - opportunity creation vs. opportunity identification (Sundqvist, } \\
\text { Kylaheiko \& Kuivalainen, 2012) }\end{array}$ \\
\hline 2 & Innovativeness & $\begin{array}{l}\text { - openness to new ideas (Frishammar \& Horte, 2007) } \\
\text { - process and product creativity (Dess \& Lumpkin, 2005) } \\
\text { - pursuit of creative or novel solutions (Knight, 2001) }\end{array}$ \\
\hline 3 & Risk taking & $\begin{array}{l}\text { - decisions in uncertainty (Dess \& Lumpkin, 2005) } \\
\text { - implementation of projects entailing significant chances of costly } \\
\text { failure (Davis, Morris \& Allen, 1991; Miller \& Friesen, 1984) }\end{array}$ \\
\hline 4 & $\begin{array}{c}\text { Competitive aggres- } \\
\text { siveness }\end{array}$ & $\begin{array}{l}\text { - competitive advantage over competitors (Dess \& Lumpkin, 2005) } \\
\text { - aggressive posturing relative to competitors (Knight, 2001) }\end{array}$ \\
\hline 5 & Autonomy & $\begin{array}{l}\text { - independent human activities (Dess \& Lumpkin, 2005) } \\
\text { - self-acting (Dess \& Lumpkin, 1996) }\end{array}$ \\
\hline
\end{tabular}

Source: Wach (2015, p.16).

\section{Innovation intensity}

The 'innovation' process comprises the technological development of an invention combined with the market introduction of that invention to end-users through adoption and diffusion (Laing, 2018). Intensity stands for something "that is highly concentrated, has a high degree of force" (Morris, 1998). II was first linked to entrepreneurial intensity which proposed to measure the intensity of the first three EO dimensions (Morris \& Sexton, 1996). That been said, there exists a relatively poor literature around the measures of II. Considering that innovativeness is a paramount dimension of EO, the intensity of innovation may provide critical information to firms in terms of innovation performance (Burns, 2013). So far, the measures proposed were the 'degree' and 'frequency' of these dimensions. This transition from EO to II was supported by Covin et al. (2006). In this sense, Burns (2013) suggested an II grid, which allows firms to map themselves on any of the four quadrants differentiated by innovation degree and frequency. Others like Coccia (2005) proposed that the intensity of technological change could be measured by an indicator, called magnitude, which was based on the impact of technological innovations on the economic system to which they aligned. Another view of intensity is financial. It may include the financial commitment of C-level managers with respect to innovation and the type of innovation activities performed (Laing, 2018).

Back to Burn's measurement scale (2013), while frequency seems relatively easy to comprehend - in terms of how many innovative product launches per year for instance, the degree of innovation is a bit more complex to assess. This latter can be associated to the innovation category: incremental, radical or disruptive.

Incremental innovation refers to a change usually involving improvement of existing products and services (Bessant, 2005) intending to achieve performance improvement. It does not require radical shifts of mindsets or substantial changes in competencies and capabilities (Garcia-Sabater, Marin-Garcia \& Perello-Marin, 2011). It is fair to say that many innovative firms play within this field as they frequently add slight innovative increments to their products, services and processes. 
Radical innovation can be seen as a deeper transformation of demand and needs of an existing market or industry [...] with significant societal impact" (Assink, 2006). Tushman and Anderson (1986) added that radicalism may relate to competence-destroying technological changes as the new innovation usually requires substantial resource commitments, and radical improvements in capabilities and competencies.

Although often confused with radical innovation, a disruption occurs when a new entrant or sometimes an incumbent comes up with an initially inferior technology according to the mainstream favorite dimension but superior on another secondary dimension(s), which then improves gradually to meet the needs of the mass market (Christensen, 1997). In that sense, low-end and new-foothold disruptions have been discussed in the literature (Christensen \& Raynor, 2003). The former describes the classical disruptive case where the new offering is of lower cost than competition due to some technological advance or a different business model. On the other hand, new-foothold stands for a disruption that starts in a niche and unserved market.

These last three types of innovation may indicate its intensity. This latter seems to increase from incremental or sustainable through radical to disruptive. In this sense, one way to measure intensity within incumbents is by looking at their innovation strategies. For instance, a spin-out specialized at the exploration activities of the parent firm is good indicator of a disruptive strategy (Christensen, 1997), while structural ambidexterity - that is combining exploitation and exploitation in parallel within the firm, is probably related to a sustaining innovation path (Tushman \& O'Reilly, 1996).

Another interesting measure of II is the degree and patterns of internationalization of the firm. As a matter of fact, both internationalization and innovation are important options to achieving firms' growth, which announces their interrelatedness. That been said, the causal relationship between these two is still controversial. So while some scholars support no link between them (e.g. Hitt, Hoskisson, \& Kim, 1997), many other studies in various industries seem to indicate that innovation capabilities of a firm have a stimulating effect on its internationalization dynamic (e.g. Cassiman \& Golovko, 2011; Denicolai, Zucchella \& Strange, 2014; Kafouros, Buckley, Sharp, \& Wang, 2008; Melitz \& Costantini, 2008; Pla-Barber \& Alegre, 2007). Based on this last view, we can hypothesize that high internationalization pace and extent may be reliable indicators of firms II level, particularly for International New Ventures (INVs) or Born Globals (BGs) that quickly set an expansionist strategy by implementing in many international markets without necessarily going through the classical stages of internationalization (Casillas \& Francisco, 2013).

While the geographic extent of internationalization is easy to assess, its pace seems multidimensional. This last topic has seen a shift in importance as early firms took relatively long time to make their first foreign sale mainly due to lack of digitization and a minor globalization rate (Johanson \& Vahlne, 1977). With INVs, the pace has increased on many levels. Namely the starting time of internationalization benchmarked to the creation date of the company has gotten shorter and shorter (Moen \& Servais, 2002). Despite the seemingly important character of these temporal metrics, many shortcomings are persisting in the literature. Hilmersson, Johanson, Lundberg and Papaioannou (2017) emphasized the need for more clarity around this concept since different measure stand for the same thing (e.g. pace, accelerated, rapid). He also suggested that the pace of internationalization is a multidimensional construct with interrelated units. The first dimension if the 
speed of international expansion. It indicates how fast a firm spreads its sales activities to various country markets (Casillas \& Moreno, 2014). The second one is "time to internationalization" to measure how soon after firm inception this latter begins its expansion abroad. The third and last dimension is the "point in time when internationalization started," which captures how long ago (or how recently) internationalization started.

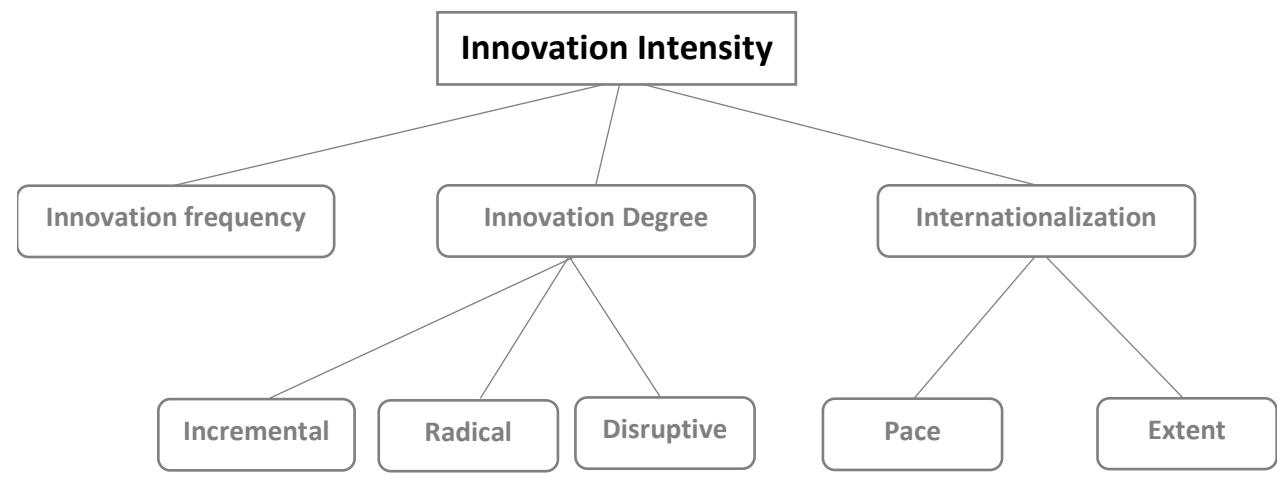

Figure 2. A proposal of II construct inspired from the extant literature Source: own elaboration.

\section{Linking entrepreneurial orientation and innovation intensity}

Because innovation is a process of combining assets, entrepreneurial orientation may facilitate the firm's ability to discern appropriate resources for combination and thus innovate (Wu et al., 2008), it seems that EO can positively influence II. Yet, there is a scarcity of research on this relationship and what other exogenous and indigenous variables may enter in play. Zheng, Yim and Tse (2005) studied the impact of strategic orientation including - Market orientation, Technology orientation and EO, on breakthrough innovation, then this latter on firm performance. There results indicated that EO positively affects both tech-based and market-based innovation. Other scholars focused on a narrower link between EO and innovation. Namely, Perez-Luno et al. (2011) demonstrated in a study of 400 Spanish firms that proactivity and risk taking -which are parts of EO construct, are positively related to the number of internally generated innovations - which may stand for "frequency" in the II construct, compared to innovation adoption and that in dynamic environments, the effect of risk taking is substantially much stronger than in stable environments. Focusing more on the exploration side, Liu et al. (2014) stated that firms with a strong EO display a better relation between unabsorbed slack. EO hence provides the capacity to more efficiently utilize internal resources in response to environmental changes. Other studies emphasized the positive link between EO and innovation performance (Alegre \& Chiva, 2013; Boso et al., 2012). Regarding the degree of II, Sheng and Chien (2016) argued that a high-level learning orientation promotes myopic learning and incremental innovation but constrains experimentation and radical innovation. 


\section{CONCLUSIONS}

Based on the synthetic review of a decade of empirical studies and the previous construct of II (cf. figure 1), there seems to be a general trend favoring a positive influence of EO on II and firm performance within various industries (cf. summary in table 3). In particular, the findings suggest that risk-taking and proactiveness, which are two main part of EO construct, contribute to a relatively high innovation and firm performance (Alegre \& Chiva, 2013; García et al., 2015; Helm et al., 2010; Muslikh et al., 2016). These findings are in phase with other scholars' confirmations or conclusions that EO positively impacts the innovative process within organizations since Top management supports new ideas and hence more resources are allocated for the exploration related activities (Bai \& Ren, 2016; Shu, Hu \& Jiang, 2015;). Furthermore, EO seems to be correlated with high extent and pace of internationalization which is in turn a good indicator of II level (Yu \& Si, 2012). EO also appears to contribute to innovation frequency (Perez-Luno et al., 2011).

One major implication of this study is a display of a lack of a precise definition and measurement scale of II and a missing link with each component of EO multi-dimensional construct. While innovation performance and success are important to study, an intermediate lacking step is to check how risk-taking (among other EO dimensions) relate to II for instance. This will allow to build a stronger picture including EO, II and eventually innovation and firm performance.

It is worth mentioning that this study is not without limitations. First, basing our review of the literature to two databases and to English articles only obviously limits the scope and assertiveness of this study. Furthermore, given that II is an understudied concept, there might be better review alternatives than looking up the term "Innovation Intensity" although it made affordable the process of narrowing down the papers scope.

Further research in this topic could inspect potential moderators (motivation, market orientation, etc.) while controlling other variables (firm size, country of origin, industry, etc.). What's the relationship between proactiveness and internationalization pace? Does proactiveness positively affects the disruptiveness level of innovation? Is autonomy a necessary factory for fast internationalization and frequent innovation level? Such results are particularly useful to enhance the entrepreneurship literature and guide up-starters willing to disrupt the market or incumbents facing disruption, mostly in fast-paced industries. 
Table 2. Countries ranked according to Hellwig's method in the years 2005-2016

\begin{tabular}{|c|c|c|c|c|}
\hline Author(s) & Research Sample & Context & Examined relationships & Findings \\
\hline $\begin{array}{l}\text { Wu, Chang, } \\
\text { \& } \\
\text { Chen (2008) }\end{array}$ & $\begin{array}{c}\text { Survey research } \\
\text { method on a cross- } \\
\text { sectional sample of } \\
159 \text { firms }\end{array}$ & $\begin{array}{l}\text { International; } \\
\text { Multi-markets }\end{array}$ & $\begin{array}{l}\text { Exploring the influence of EO and } \\
\text { social capital on intellectual } \\
\text { capital, as well as the influence of } \\
\text { intellectual capital on innovation }\end{array}$ & $\begin{array}{l}\text { EO tends to significantly influence intellectual capital, including human } \\
\text { capital, customer capital, and structural capital. The characteristics of } \\
\text { risk-taking, innovativeness, and proactiveness, which stand for EO, are } \\
\text { the key to fully implementing intellectual capital in order to create } \\
\text { higher levels of innovation }\end{array}$ \\
\hline $\begin{array}{l}\text { Renko, } \\
\text { Carsrud, \& } \\
\text { Brännback } \\
(2009)\end{array}$ & \begin{tabular}{|} 
Semi-structred \\
interviews with 85 \\
venture CEOs and \\
business \\
development \\
managers
\end{tabular} & $\begin{array}{c}\text { Finish, Swedish } \\
\text { and American } \\
\text { BioTech firms }\end{array}$ & $\begin{array}{l}\text { Testing the link between } \\
\text { Technological capability, Market } \\
\text { orientation and EO on one-side, } \\
\text { and product innovativeness on the } \\
\text { other }\end{array}$ & $\begin{array}{l}\text { Market orientation shares a positive relationship with capital invested } \\
\text { in the firm, specifically in Sweden and Finland. Market orientation is } \\
\text { not related to product innovativeness measurements. Technological } \\
\text { capability is a positive predictor of product innovativeness. EO is not } \\
\text { related to product innovativeness. EO is not positively related to capital } \\
\text { invested in the biotechnology venture either }\end{array}$ \\
\hline $\begin{array}{l}\text { Helm, } \\
\text { Mauroner, } \\
\text { Dowling } \\
(2010)\end{array}$ & $\begin{array}{l}165 \text { surveys done } \\
\text { by the founders }\end{array}$ & $\begin{array}{l}\text { High } \\
\text { technology } \\
\text { spin-off } \\
\text { companies in } \\
\text { Germany }\end{array}$ & \begin{tabular}{|l|} 
OO, in particular risk-taking \\
behavior and proactivity, is of \\
particular importance in the \\
context of high-technology venture \\
success. Innovativeness as a \\
mediator.
\end{tabular} & $\begin{array}{l}\text { The results suggest that especially in high technology sectors and in fast } \\
\text { growing markets, such as biotechnology, healthcare, information } \\
\text { technology and optics where innovation is necessary to endure, a } \\
\text { pronounced EO is important. Furthermore, innovativeness as a central } \\
\text { entrepreneurial object mediates between the motivation and the success } \\
\text { of entrepreneurs. }\end{array}$ \\
\hline $\begin{array}{l}\text { Yu \& Si } \\
(2012)\end{array}$ & 109 questionnaires & $\begin{array}{c}109 \text { Chinese } \\
\text { listed } \\
\text { entrepreneurial } \\
\text { firms }\end{array}$ & $\begin{array}{l}\text { Examining the relationships } \\
\text { between firms' international IPO } \\
\text { listing and R\&D intensity, and how } \\
\text { innovation capacity relates to } \\
\text { entrepreneurial performance }\end{array}$ & $\begin{array}{l}\text { Firms' II and their pursuit of internationalization seems to be } \\
\text { interrelated in that innovation capabilities can provide a strong push } \\
\text { for internationalization. The relationship with foreign institutions and } \\
\text { R\&D investments are two important indicators of new ventures' } \\
\text { innovation capacities and potential drivers of a firm's } \\
\text { internationalization. }\end{array}$ \\
\hline
\end{tabular}




\begin{tabular}{|c|c|c|c|c|}
\hline Author(s) & Research Sample & Context & Examined relationships & Findings \\
\hline $\begin{array}{l}\text { Boso et al., } \\
(2012)\end{array}$ & $\begin{array}{l}\text { Questionnaire sent } \\
\text { to } 164 \text { firms }\end{array}$ & $\begin{array}{l}\text { Ghanaian } \\
\text { exporters }\end{array}$ & \begin{tabular}{|l|} 
Inspecting the relationship \\
between Entrepreneurial-oriented \\
behavior and export product \\
innovation success
\end{tabular} & $\begin{array}{l}\text { The findings indicate that both export entrepreneurial-oriented behavior } \\
\text { and export market-oriented behavior drive export product } \\
\text { innovation success. Moreover, EO behavior is more likely to be a driver } \\
\text { of product innovation success when market-oriented behavior is strong }\end{array}$ \\
\hline $\begin{array}{l}\text { Liu et al. } \\
(2014)\end{array}$ & $\begin{array}{l}308 \text { final sample } \\
\text { from face-to-face } \\
\text { interviews with } \\
\text { senior top } \\
\text { managers and } \\
\text { division leaders }\end{array}$ & $\begin{array}{l}\text { Chinese } \\
\text { High-Tech } \\
\quad \text { firms }\end{array}$ & $\begin{array}{l}\text { Inspecting the relationship } \\
\text { between unabsorbed slack and } \\
\text { product innovation on one hand, } \\
\text { and EO absorbed slack and product } \\
\text { innovation on the other }\end{array}$ & $\begin{array}{l}\text { Firms with a strong EO display a better relation between unabsorbed } \\
\text { slack and innovation but a worse relation between absorbed slack and } \\
\text { innovation. EO provides the capacity to more efficiently utilize internal } \\
\text { resource combinations in response to environmental changes }\end{array}$ \\
\hline $\begin{array}{l}\text { García et al. } \\
(2015)\end{array}$ & $\begin{array}{c}182 \text { surveys from } \\
\text { personal interviews } \\
\text { with managers }\end{array}$ & $\begin{array}{l}\text { Spanish and } \\
\text { Italian } \\
\text { ceramic tile } \\
\text { industry }\end{array}$ & $\begin{array}{l}\text { examining the possibility of a } \\
\text { connection between managerial } \\
\text { risk-taking propensity, risk-taking } \\
\text { climate and innovation } \\
\text { performance }\end{array}$ & $\begin{array}{l}\text { Managerial risk taking is positively related to a risk-taking climate. Firms' } \\
\text { risk taking climate matters to enhance innovation performance. } \\
\text { Furthermore, managers' risk-taking propensity has an indirect positive } \\
\text { effect on firms' innovation performance, which is mediated by a risk-taking } \\
\text { climate. }\end{array}$ \\
\hline $\begin{array}{l}\text { Muslikh, } \\
\text { Byarwati, } \\
\text { Hidayati } \\
\text { (2016) }\end{array}$ & $\begin{array}{l}104 \text { questionnaires } \\
\text { sent to CEOs }\end{array}$ & $\begin{array}{l}\text { Indonesian } \\
\text { SMEs in } \\
\text { Tourism }\end{array}$ & $\begin{array}{l}\text { Testing the effect of EO, market } \\
\text { orientation, knowledge sharing, } \\
\text { competence, to competitiveness } \\
\text { with innovation, and creativity as } \\
\text { mediator }\end{array}$ & $\begin{array}{l}\text { The results indicate that } \mathrm{EO} \text { and market orientation influence } \\
\text { innovation, knowledge sharing. Creativity influence innovation and this } \\
\text { latter influence competitiveness while creativity has non-significant } \\
\text { influence on competitiveness }\end{array}$ \\
\hline $\begin{array}{l}\text { Jing and al. } \\
(2016)\end{array}$ & $\begin{array}{l}264 \text { questionnaires } \\
\text { sent to managers }\end{array}$ & $\begin{array}{c}\text { industrial } \\
\text { Chinese firms }\end{array}$ & $\begin{array}{l}\text { The influence of (EO) and HRM on } \\
\text { ambidexterity }\end{array}$ & $\begin{array}{l}\text { the study suggests that the interaction between EO and capability-based } \\
\text { HRM facilitates innovation ambidexterity, and its relationship with firm } \\
\text { performance is mediated by innovation ambidexterity }\end{array}$ \\
\hline $\begin{array}{l}\text { Peng, } \\
\text { Michael, } \\
\text { Xiaofeng } \\
(2016) \\
\end{array}$ & $\begin{array}{l}\text { Mail survey } \\
\text { responded by a } \\
\text { sample of } 153 \text { firms }\end{array}$ & $\begin{array}{c}\text { Random new } \\
\text { ventures }\end{array}$ & $\begin{array}{l}\text { Examining the mediating role of } \\
\text { innovation speed in the } \\
\text { relationship between EO and } \\
\text { performance }\end{array}$ & $\begin{array}{l}\text { Results show that faster innovation speed leads to superior } \\
\text { performance. In addition, autonomy and competitive aggressiveness are } \\
\text { found to increase innovation speed as predicted. However, risk-taking } \\
\text { reduces innovation speed }\end{array}$ \\
\hline $\begin{array}{l}\text { Sheng, Chien } \\
(2016)\end{array}$ & $\begin{array}{c}200 \text { usable } \\
\text { questionnaires }\end{array}$ & $\begin{array}{c}\text { 70 Taiwan- } \\
\text { based High- } \\
\text { Tech companies }\end{array}$ & $\begin{array}{l}\text { Relationship between learning } \\
\text { orientation and radical innovation }\end{array}$ & $\begin{array}{l}\text { The results show that a high-level learning orientation promotes myopic } \\
\text { learning and incremental innovation but constrains experimentation and } \\
\text { radical innovation in emerging domains. }\end{array}$ \\
\hline
\end{tabular}

Source: own study. 


\section{REFERENCES}

Alegre, J., \& Chiva, R. (2013). Linking Entrepreneurial Orientation and Firm Performance: The Role of Organizational Learning Capability and Innovation Performance. Journal of Small Business Management, 51(4), 491-507.

Antoncic, B., \& Hisrich, R. (2003). Clarifying the intrapreneurship concept, Journal of Small Business and Enterprise Development, 10(1), 7-24. https://doi.org/10.1108/14626000310461187.

Arzubiaga, U., Kotlar, J., Massis, A.D., Maseda, A., Iturralde, T. (2018). Entrepreneurial orientation and innovation in family SMEs: Unveiling the (actual) impact of the Board of Directors. Journal of Business Venturing, 33, 455-469.

Assink, M. (2006). Inhibitors of disruptive innovation capability: a conceptual model. European Journal of Innovation Management, 9(12), 215-233.

Awang, A., Amran, S., Nor, M. N. M., Ibrahim, I. I., \& Razali, M. F. M. (2016). Individual entrepreneurial orientation impact on entrepreneurial intention: Intervening effect of PBC and subjective norm. Journal of Entrepreneurship, Business and Economics, 4(2), 94-129.

Bai, J., \& Ren, J. (2016). Organizational ambidexterity and innovation performance: The moderating effect of entrepreneurial orientation. Frontiers of Business Research in China, 10(4), 664-693.

Bessant, J. (2005). Enabling continuous and discontinuous innovation: Learning from the private sector. Public Money \& Management, 25(1), 35-42.

Boso, N., Cadogan, J. W. \& Story V.M. (2012). Entrepreneurial orientation and market orientation as drivers of product innovation success: a study of exporters from a developing economy. International Small Business Journal, 31(1), 57-81.

Burns, P. (2013). Corporate Entrepreneurship: Building an entrepreneurial organization. Macmillan International Higher Education, 39(1), 1-194.

Casillas, J.C., \& Francisco, J.A. (2013). Speed in the Internationalization Process of the Firm. International Journal of Management Reviews, 15(1), 15-29.

Casillas, J. \& Moreno, A. (2014). Speed of the internationalization process: The role of diversity and depth in experiential learning. Journal of International Business Studies, 45, 85-101.

Cassiman, B., \& Golovko, E., (2011). Innovation and internationalization through exports. J Int Bus Stud, 42, 56-75.

Christensen, C. M. (1997). The Innovator's Dilemma: When New Technologies Cause Great Firms to Fail. Boston: Harvard Business School Press.

Christensen, C.M, \& Raynor, M. (2003). The Innovator's Solution: Creating and Sustaining Successful Growth. Boston: Harvard Business School Press.

Coccia, M., (2005). Measuring Intensity of Technological Change: The Seismic Approach. Technological Forecasting \& Social Change, 72(2), 117-144.

Covin, J.G., Green, K.M., \& Slevin, D.P. (2006). Strategic process effects on the entrepreneurial orientation - sales growth rate relationships. Entrepreneurship Theory and Practice, 30(1), 57-81.

Covin, J.G., \& Slevin, D.P. (1991). A conceptual model of entrepreneurship as firm behavior. Entrepreneurship Theory and Practice, 16(1), 7-25.

Davis, D., Morris, M., \& Allen, J. (1991). Perceived environmental turbulence and its effect on selected entrepreneurship, marketing, and organizational characteristics in industrial firms. Journal of the Academy of Marketing Science, 19 (1), 43-51.

Denicolai, S., Zucchella, A., \& Strange, R. (2014). Knowledge assets and firm international performance. International Business Review, 23, 55-62.

Dess, G.G. \& Lumpkin, G.T. (1996). Clarifying the Entrepreneurial Orientation Construct and linking it to Performance. The Academy of Management Reviews, 21(1), 135-172.

Dess, G.G., \& Lumpkin, G.T. (2005). The role of entrepreneurial orientation in stimulating corporate entrepreneurship: research briefs. Academy of Management Executive , 19(1), 147-156. 
Eggers, F., Kraus, S., Hughes, M., Laraway, S., \& Snycerski S. (2013). Implications of customer and entrepreneurial orientations for SME growth. Management Decision, 51(3), 524-546. https://doi.org/10.1108/00251741311309643.

Frishammar, J., \& Andersson, S. (2009). The overestimated role of strategic orientations for international performance in smaller firms. Journal of International Entrepreneurship, 7(1), $57-77$.

García G. A., Llopis, O., Fernández A.M., \& Alegre, J. (2015). Unraveling the link between managerial risk-taking and innovation: The mediating role of a risk-taking climate. Journal of Business Research, 68, 1094-1104.

Garcia-Sabater, J.J., Marin-Garcia, J.A., \& Perello-Marin, M.R. (2011). Is implementation of continuous improvement possible? An evolutionary model of enablers and inhibitors. Human Factors and Ergonomics in Manufacturing, 19(2), 110-132.

Helm, R., Mauroner, O., \& Dowling, M. (2010). Innovation as mediator between entrepreneurial orientation and spin-off venture performance. International Journal of Entrepreneurship and Small Business, 11(4), 472-491.

Hilmersson, M., Johanson, M., Lundberg, H., \& Papaioannou, S. (2017). Time, Temporality, and Internationalization: The Relationship among Point in Time of, Time to, and Speed of International Expansion. Journal of International Marketing, American Marketing Association. 25(1), 22-45. https://doi.org/10.1509/jim.16.0013.

Hitt, M.A., Hoskisson, R.E., \& Kim, H. (1997). International diversification: effects on innovation and firm performance in product-diversified firms. The Academy of Management Journal, 40(4), 767-798.

Horney, N., Pasmore, B., \& O'Shea, T., (2010). Leadership agility: a business imperative for a VUCA world. People Strategy, 33 (4), 32-38.

Hosseini, M.G. (2012). Human resource accounting. IOSR Journal of Business and Management, 2(5), 6-10.

Jing, A. Z., Edgar, F., Geare, G., \& O'Kane, C. (2016). The interactive effects of entrepreneurial orientation and capability based HRM on firm performance: The mediating role of innovation ambidexterity. Industrial Marketing Management, 59, 131-143.

Johanson, J., \& Vahlne J.E. (1977). The Internationalization Process of the Firm: A Model of Knowledge Development and Increasing Foreign Market Commitments. Journal of International Business Studies, 8, 23-32.

Jorge, F. (2018). Dynamic capabilities, creativity and innovation capability and their impact on competitive advantage and firm performance: The moderating role of entrepreneurial orientation. Technovation. DOI: 10.1016/j.technovation.2018.11.004.

Kafouros, M.I., Buckley, P.J., Sharp, J.A., Wang, C. (2008). The role of internationalization in explaining innovation performance. Technovation, 28, 63-74.

Knight, G.A. (2001). Entrepreneurship and strategy in the international SME. Journal of International Management, 7(3), 155-171.

Laing, K. G. (2018). Seismic Measurement of Management Accounting Innovations: Using the Scale of Innovation Intensity. Management Accounting Frontiers, 1, 3-14.

Liu, H., Ding, X.-h., Guo, H., \& Luo, J.h. (2014). How does slack affect product innovation in high-tech Chinese firms: The contingent value of entrepreneurial orientation. Asia Pacific Journal of Management, 31(1), 47-68. DOI: 10.1007/s10490-012-9309-5.

Melitz, M.J., \& Costantini, J.A. (2008). The dynamics of firm level adjustment to trade liberalization. In: Helpman E., Marin D., Verdier T. (eds). The organization of firms in a global economy (107141). Massachusetts: Harvard University Press.

Miller, D. (2011). Miller (1983) revisited: A Reflection on EO Research and Some Suggestions for the Future. Entrepreneurship Theory and Practice, 35(5), 873-894.

Miller, D., \& Friesen, P. (1984). Organizations: A Quantum View. Englewood Cliffs: Prentice-Hall.

Moen, $\varnothing$., \& Per, S. (2002). Born Global or Gradual Global? Examining the Export Behavior of Small and Medium-Sized Enterprises. Journal of International Marketing, 10 (3), 49-72. 
Morris, M.H. (1998). Entrepreneurial Intensity: Sustainable Advantages for Individuals, Organizations, and Societies. USA. Praeger.

Morris, M.H., \& Sexton, D.L. (1996). The concept of entrepreneurial intensity: Implications for company performance. Journal of Business Research, 36(1), 5-13.

Muslikh, M., Byarwati, A., \& Hidayati, R. (2016). How to improve the competitiveness of SME's products in tegalwaru tourism village bogor. Man in India, 96(11), 4225-4240.

Peng, S., Michael, S., \& Xiaofeng, J. (2016). Entrepreneurial orientation and performance: Is innovation speed a missing link. Journal of Business Research, 69, 683-690.

Perez-Luno, A., Wiklund, J., \& Valle Cabrera, R. (2011). The dual nature of innovative activity: How entrepreneurial orientation influences innovation generation and adoption. Journal of Business Venturing, 26(5), 555-571. DOI: 10.1016/j.jbusvent.2010.03.001.

Pla-Barber, J., \& Alegre, J. (2007). Analysing the link between export intensity, innovation and firm size in a science-based industry. International Business Review, 16, 275-293.

Rauch, A., Wiklund, J., Lumpkin, G.T., \& Frese, M. (2009). Entrepreneurial Orientation and Business Performance: An Assessment of Past Research and Suggestions for the Future. Entrepreneurship: Theory and Practice, 33(3), 761-787.

Renko, M., Carsrud, A., \& Brännback, M. (2009). The Effect of a Market Orientation, Entrepreneurial Orientation, and Technological Capability on Innovativeness: A Study of Young Biotechnology Ventures in the United States and in Scandinavia. Journal of Small Business Management, 47(3), 331-369.

Sheng, L. M., \& Chien, I. (2016). Rethinking organizational learning orientation on radical and incremental innovation in high-tech firms. Journal of Business Research, 69, 2302-2308.

Shu, C. L., Hu, Y. F., \& Jiang, X. (2015). Learning ambidexterity, knowledge acquisition and innovation performance in strategic alliances. $R \& D$ Management, 27(6), 97-106.

Sundqvist, S., Kylaheiko, K., \& Kuivalainen, O. (2012). Kirznerian and Schumpeterian entrepreneurialoriented behavior in turbulent export markets. International Marketing Review, 29(2), 203-219.

Therrien, P., Doloreux, D., \& Chamberlin, T. (2011). Innovation Novelty and (Commercial) Performance in the Service Sector: A Canadian Firm-Level Analysis. Technovation, 31, 655665. http://dx.doi.org/10.1016/j.technovation.2011.07.007.

Tushman, M.L., \& Anderson, P. (1986). Technological Discontinuities and Organizational Environments Administrative. Science Quarterly, 31(3), 439-465.

Tushman, M.L., \& O'Reilly, C.A. (1996). The ambidextrous organization: managing evolutionary and revolutionary change. California Management Review, 38, 1-23.

Wach, K. (2015). Entrepreneurial Orientation and Business Internationalisation Process: The Theoretical Foundations of International Entrepreneurship. Entrepreneurial Business and Economics Review, 3(2), 9-24.

Wales, W.J., Gupta, V.K., \& Mousa, F. (2013) Empirical Research on entrepreneurial orientation: an assessment and suggestions for future research. International Small Business Journal, 31(4), 357-383.

Wiklund, J., \& Shepherd, D. (2003). Knowledge-based resources, entrepreneurial orientation, and the performance of small and medium-sized businesses. Strategic Management Journal, 24(13). https://doi.org/10.1002/smj.360.

Wu, W.-Y., Chang, M.L., \& Chen, C.W. (2008). Promoting innovation through the accumulation of intellectual capital, social capital, and entrepreneurial orientation. R\&D Management, 38(3), 265-277. DOI: 10.1111/1467-9914.00120-i1.

Yu, X., \& Si, S. (2012). Innovation, internationalization and entrepreneurship: A new venture research perspective. Innovation: Management, policy \& practice, 14(4), 524-539.

Zheng, Z. K., Yim, B., \& Tse, K. D. (2005). The Effects of Strategic Orientations on Technology- and Market-Based Breakthrough Innovations. Journal of Marketing, 69, 42-60. 


\section{Author}

\section{Nizar M. Benazzouz}

Master in IT management (Engineering School of Telecom ParisTech, France); International Master in Business Administration (Sorbonne University, France). Currently working as digital portfolio manager within an SME. His research interests include innovation management and international entrepreneurship.

Correspondence to: ni.benazzouz@gmail.com

\section{Acknowledgements and Financial Disclosure}

The Author would like to thank Prof. Krzysztof Wach as his doctoral supervisor and two anonymous reviewers for their value comments.

\section{Copyright and License}

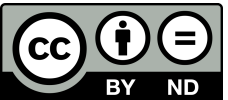

This article is published under the terms of the Creative Commons

Attribution - NoDerivs (CC BY-ND 4.0) License

http://creativecommons.org/licenses/by-nd/4.0/

\section{Published by the Centre for Strategic and International Entrepreneurship - Krakow, Poland}

